\title{
UPAYA MENINGKATKAN HASIL BELAJAR PESERTA DIDIK PADA MATA PELAJARAN IPS MENGGUNAKAN METODE PICTURE AND PICTURE KELAS III SDN-1 KASONGAN LAMA TAHUN PELAJARAN 2016/2017
}

\author{
Oleh : Nova Karlina*Ichyatul Afrom, M.Pd
}

\begin{abstract}
Abstrak
Penelitian ini bertujuan untuk mengetahui aktivitas dan peningkatan hasil belajar peserta didik dalam pembelajaran IPS pada materi jenis - jenis pekerjaan dengan menggunaka metode picture and picture di kelas III SDN-1 Kasongan Lama.Metode penelitian yang digunakan dalam penelitian ini adalah metode Penelitian Tindakan Kelas (PTK) dengan subjek penelitian seluruh peserta didik kelas III yang berjumlah 20 orang. Teknik analisis data menggunakan analisis kualitatif dan kuantitatif didasarkan pada hasil siklus pada tiap proses pembelajaran.

Hasil penelitian menunjukan bahwa : (1) Aktivitas peserta didik pada saat proses pembelajaran IPS dengan menggunakan metode picture and picture pada kelas III SDN - 1 Kasongan Lama lebih aktif. Hal ini dibuktikan dengan hasil rata rata aktivitas peserta didik pada siklus I yaitu 3.3 yang termasuk kategori (baik) dan hasil rata - rata aktivitas guru pada siklus I diperoleh nilai 3,4 yang termasuk kategori (baik); (2) ada peningkatan hasil belajar IPS peserta didik setelah proses pembelajaran dengan menggunakan metode picture and picture pada peserta didik di kelas III SDN-1 Kasongan Lama. Hal ini dibuktikan dengan hasil belajar peserta didik pada siklus I diperoleh nilai rata - rata yaitu 80 dengan persentase ketuntasan hasil belajar klasikal mencapai $90 \%$.
\end{abstract}

\section{Kata kunci :IPS, Metode picture and picture.}

\section{PENDAHULUAN}

Pendidikan merupakan upaya yang strategis meningkatkan sumber daya manusia dan upaya mewujudkan cita - cita bangsa Indonesia dalam mewujudkan kesejahteraan umum dan mencerdaskan kehidupan bangsa. Hal ini sesuai dengan tujuan guruan nasional Nomor 20 Tahun 2003 Tentang Sistem Pendidikan Nasional (dalam Hasbullah, 2005:307) adalah sebagai berikut : pendidikan nasional berfungsi mengembang kan kemampuan dan membentuk watak serta peradaban bangsa yang bermartabat dalam rangka mencerdaskan kehidupan bangsa, bertujuan untuk berkembang nya potensi peserta didik agar menjadi manusia beriman dan bertakwa kepada Tuhan Yang Maha Esa, berakhlak mulia, sehat, berilmu, cakap kreatif, mandiri dan menjadi warga negara yang demokratis serta bertanggung jawab.

Dalam rangka mencapai tujuan pendidikan nasional tersebut, banyak hal yang harus dipersiapkan terutama yang berkenaan dengan masalah pendidikan, diantaranya faktor guru, peserta didik, kurikulum, metode pembelajaran, sarana dan perasarana 
dan lain sebagainya. Proses pembelajaran merupakan aktivitas penting, karena melalui proses pembelajaran itulah tujuan pendidikan akan tercapai dalam bentuk perubahan perilaku peserta didik. Di dalam proses pembelajaran di kelas sering kali dihadapkan dengan berbagai masalah. Salah satu dari permasalahan tersebut adalah rendahnya hasil belajar peserta didik dalam proses pembelajaran. Hasil belajar proses pembelajaran mempunyai peranan penting dalam rangka untuk memahami suatu materi pelajaran tertentu. Selama ini ditemukan masih banyak di dalam proses belajar mengajar di kelas yang kurang mendorong proses peserta didik untuk bersemangat mengikuti pembelajaran. Pada prinsipnya penyampaian materi akan lebih mudah dipahami dan diterima peserta didik apabila dalam proses pembelajaran itu terasa menyenangkan dan membuat peserta didik tertarik untuk memahami materi yang di sampaikan.

$\begin{array}{ccr}\text { Usaha }- & \text { usaha } & \text { dalam } \\ \text { membelajarkan } & \text { peserta } & \text { didik }\end{array}$ merupakan bagian yang sangat penting dalam mencapai keberhasilan tujuan pembelajaran yang sudah direncanakan oleh karena itu pemilihan metode pembelajaran merupakan suatu hal yang utama metode pembelajaran adalah pedoman berupa program atau petunjuk strategi mengajar yang direncana untuk mencapai suatu tujuan pembelajaran. Metode pembelajaran memiliki kekuatan yang bersinegri positif yang mampu merubah sikap dan tingkah laku, hasil belajar peserta didik kearah perubahan yang kreatif, aktif dan dinamis.

Dimata pelajaran IPS merupakan salah satu pengetahuan dasar yang penting dalam menunjang ilmu pengetahuan dan teknologi.Oleh karena itu pelajaran IPS diberikan secara berkesinabungan pada setiap jenjang pendidikan formal dari sekolah dasar sampai pada kelanjutan yang lebih tinggi.

Rendahnya hasil belajar IPS seringkali disebabkan oleh beberapa faktor ataupun permasalahan yang mempengaruhi selama proses pembelajaran berlangsung. Kurangnya pemanfaatan sumber belajar sehingga penanaman konsep IPS masih rendah dan peserta didik hanya berimajinasi tanpa adanya praktek yang nyata. Selain beberapa faktor yang menyebabkan kurangnya hasil belajar IPS pada peserta didik kelas III di SDN-1 Kasongan Lama, berdasarkan hasil observasi yang saya lakukan, ada pula beberapa kendala ataupun masalah yang ada saat proses pembelajaran IPS berlangsung, pada peserta didik kelas III di SDN-1 Kasongan Lama, Kecamatan Katingan Hilir, Kabupaten Katingan, diantaranya yaitu :

1. Metode yang digunakan kurang bervariasi.

2. Antusias peserta didik dalam belajar IPS masih rendah.

3. Peserta didik mudah bosan dan kurang bersemangat pada saat proses pembelajaran.

4. Kurang aktifnya peserta didik pada proses pembelajaran IPS

5. Hasil belajar peserta didik masih rendah dibawah (KKM). 
Berdasarkan observasi yang peneliti laksanakan pada hari Senin, 09 Januari. Pukul 07.00 08.30, pada peserta didik kelas III di SDN-1 Kasongan Lama, Kecamatan Katingan Hilir, Kabupaten Katingan, terhadap masalah yang dilakukan walikelas tersebut sekaligus selaku guru mata pelajaran Ilmu Pengetahuan Sosial salah satunya adalah rendahnya hasil belajar peserta didik. Hal tersebut ditandai dengan hasil evaluasi yang guru lakukan pada hari Senin, 09 januari 2017 menunjukan bahwa kemampuan peserta didik dalam memahami materi "Jenis- jenis pekerjaan" masih rendah yang dimana rata rata masih dibawah kriteria ketuntasan minimal yang ditentukan sekolah yaitu 65 dinyatakan berhasil.

\section{METODOLOGI}

Adapun jenis penelitian yang digunakan dalam kelas (PTK) yang bertujuan untuk melakukan perbaikan - perbaikan terhadap sistem, isi dan kompetensi atau situasi pembelajaran dengan menguji cobakan suatu ide kedalam praktis dan situasi yang nyata dalam proses belajar mengajar di kelas dengan harapan kegiatan tersebut dapat meningkatkan hasil proses belajar mengajar. Menurut kunandar (2012:45) penelitian tindakan kelas yang dilakukan denga tujuan memperbaiki mutu praktik pembelajaran dikelas".
Menurut (Wiria atmadja 2006:13), penelitian tindakan kelas adalah bagaimana sekelompok guru dapat mengorganisasikan kondisi keaktifan pembelajaran mereka, dan belajar dari pengalaman mereka sendiri. Mereka dapat mencobakan suatu gagasan perbaikan dalam praktik pembelajaran mereka, dan melihat pengaruh nyata dari upaya itu.Peneliti ini berusaha menjawab permasalahan yang diajukan peneliti yaitu pembelajaran dengan penerapan metode picture and picture untuk meningkatkan hasil belajar IPS materi jenis - jenis pekerjaan pada peserta didik kelas III SDN-1 Kasongan Lama Tahun Pelajaran 2016/2017.(Suharsimi Arikunto,2006:17-21) bahwa terdapat 3 tahap yang lazim dilalui yaitu (1) perencanaan, pelaksanaan, (3) pengamatan

\section{HASIL DAN PEBAHASAN}

Berdasarkan perhitungan nilai rata - rata dan ketuntasan hasil belajar, didapat hasil belajar tes awal peserta didik kelas III SDN-1 Kasongan Lama didapat nilai rata rata sebesar 5,5 dan ketntasan belajar sebesar 35\% yang termasuk dalam kriteria sangat kurang tercapai. Nilai rata - rata yang diperoleh peserta didik 5,5 masih belum memenuhi kriteria ketuntasan minimal 65 dan nilai ketuntasan klasikal 85\%. Sehingga pada tes awal dalam ketetapan tingkat ketercapaian keberhasilan pembelajaran belum memenuhi syarat ketuntasan belajar. 
Data dari hasil pretest yang dilakukan pada saat pra siklus/ pratindakan terdapat 6 peserta didik yang mencapai kriteria ketuntasan minimal (KKM) yang sudah ditetapkan yaitu 65. Pada siklus I 20 peserta didik tersebut yang akan dijadikan foks penelitian. Skor aktivitas belajar didik saat proses pembelajar IPS dengan menggunakan metode picture and picture lebih bai.Pada siklus I ada 18 orang peserta didik yang tuntas atau mencapai nilai ketuntasan minimm. Jumlah peserta didik yang tidak tuntas ada 2 orang peserta didik yang tidak tuntas. Dari hasil belajar tersebut maka dapat diketahui peningkatan sebelum dan setelah dilakukannya tindakan, hasil penelitian ini juga memperkat bahwa metode pembelajara picture and picture dapat meningkatkan hasil belajar peserta didik Dalam penelitian tersebut terdapat peningatan hasil belajar IPS peserta didik setelah menggunakan metode picture and

2. Ada peningkatan hasil belajar IPS dengan menggunakan metode picture and picture pada peserta didik kelas III SDN-1 Kasongan Lama. Hal tersebut sesuai dengan data yakni tes awal (pre-test) rata rata hasil belajar peserta didik 60 meningkat pada siklus I menjadi rata - rata 80 , dengan nilai klasikal peserta didik $90 \%$ peserta didik pada siklus I rata rata 3,4 sehingga aktivitas peserta didik pada siklus Isudah dapat dikatakan baik. Berarti peningkatan aktivitas belajar peserta didik seperti yang diungkapkan diatas sudah terpenuhi sesuai hipotesis peneliti yang menyatakan bahwa aktivitas belajar peserta picture. hal ini dapat dibuktikan dari hasil rata - rata belajar pre test yaitu 5,5 rata - rata post test siklus

\section{KESIMPULAN}

1. 1. Aktivitas belajar peserta didik dalam pembelajaran IPS dengan menggunakan metode picture and picture pada peserta didik kelas III SDN-1 Kasongan Lama menjadi baik. Hal itu terlihat dari keaktifan, antusias, dan semangat peserta didik dalam mengikuti pembelajaran, dengan data observasi pada siklus I aktivitas guru memperoleh rata - rata 3,4 dengan kategori baik sedangkan aktivitas peserta didik 3,3 dengan kategori baik.

\section{DAFTAR PUSTAKA}

Hasbullah.2005.Metodologi penelitian pendidikan. Jakarta: PT Rineka cipta.

Kunandar.2012 langkah Mudah Penelitian Tindakan Sebagai Pengembangan Profesi Guru.Jakarta : Raja Grafindo Persada. 
Tunas Jurnas Pendidikan Guru Sekolah Dasar, Juni 2018 Volume 3 Nomor 2, (12-16) ISSN 2477-6076 